\title{
Case study: influence of performance levels of ABNT NBR 15575 without consumption of materials used in reinforced concrete structures
}

\section{Estudo de caso: influência dos níveis de desempenho da ABNT NBR 15575 no consumo de materiais utilizados em estruturas de concreto armado}
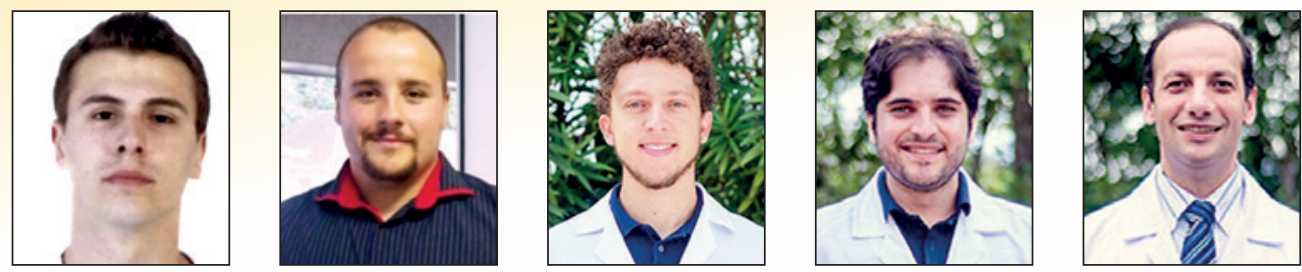

F. S. CUNHA

fselaucunha@gmail.com https://orcid.org/0000-0001-7496-3908

K. A. L. COLLA klebercolla@hotmail.com https://orcid.org/0000-0002-5234-920X

$\begin{array}{r}\text { H. EHRENBRING a } \\ \text { hzamis@unisinos.com }\end{array}$
https://orcid.org/0000-0002-0339-9825
https://orcid.org/0000-0002-0495-099X
$\begin{array}{r}\text { F. L. BOLINA a } \\ \text { B. TUTIKIAN a }\end{array}$
https://orcid.org/0000-0003-1319-0547
bftutikiannisinos.br

\begin{abstract}
The Brazilian construction industry still discusses the consequence of the Performance Standard on housing developments. According to ABNT NBR 15575 [1], the systems that compose residential buildings need to meet minimum performance requirements. Among the systems, the structural must reach a minimum Service Life (SL) of 50 years, or intermediate or higher that corresponds to 63 and 75 years, respectively. The industry also debates the impact and viability of increasing the SL of reinforced concrete structures. Therefore, this article aimed to analyze a single reinforced concrete building designed for the 3 SL specified by ABNT NBR 15575 [1]. The study focused on the total consumption of steel and concrete. The structure's designed conditions of exposure were varied for each performance level, based on the 4 environmental exposure classes (EEC) of ABNT NBR 6118 [3] and ABNT NBR 12655 [11], totalizing 12 situations. It was noted that the increased performance level increases consumption of materials, and the designs made for EEC IV consumed $12.3 \%$ and $16.2 \%$ more steel and concrete at the intermediate and superior performance levels respectively, when compared to the minimum performance level.
\end{abstract}

Keywords: brazilian performance standard, concrete strcuture, service life.

\section{Resumo}

O setor da construção civil ainda discute a consequência da Norma de Desempenho nas edificações habitacionais. Segundo a ABNT NBR 15575 [1], os sistemas que compõem edificações residenciais necessitam atingir os requisitos mínimos de desempenho. Dentre os sistemas, o estrutural deve atender a uma Vida Útil de Projeto (VUP) mínima de 50 anos, ou intermediária ou superior, correspondendo à 63 e 75 anos, respectivamente. É debatido no setor o impacto e a viabilidade do incremento da VUP nas estruturas de concreto armado. Diante disso, esse artigo objetivou analisar uma mesma edificação em concreto armado projetada para as 3 VUPs contempladas pela ABNT NBR 15575 [1]. O estudo concentrou-se no consumo total de aço e concreto. Para cada nível de desempenho, variaram-se as condições de exposição da estrutura para o dimensionamento, com base nas 4 classes de agressividade ambiental (CAA) da ABNT NBR 6118 [3] e ABNT NBR 12655 [11], totalizando 12 situações. Verificou-se que o incremento do nível de desempenho aumenta o consumo dos materiais, sendo que os projetos elaborados para a CAA IV tiveram um consumo de $12,3 \%$ e $16,2 \%$ de aço e concreto superior para os níveis intermediário e superior de desempenho, respectivamente, comparando com o nível mínimo de desempenho.

Palavras-chave: norma de desempenho, estruturas de concreto armado, vida útil de projeto.

Unisinos, itt Performance, São Leopoldo, RS, Brasil.

Received: 16 Mar 2018 • Accepted: 30 Nov 2018 • Available Online: 08 Aug 2019

बलre This is an open-access article distributed under the terms of the Creative Commons Attribution License 


\section{Introduction}

The Brazilian construction industry has shown notorious reactions to the implementation of ABNT NBR 15575 [1]. The standard determines minimum performance requisites that must be applied to systems that make up housing developments to meet requirements of habitability, safety and sustainability [2]. For each requirement, the standard defines minimum, intermediate and superior performance levels, with direct consequences to their stages of use. Among these concepts is the SL, the minimum timespan that systems must remain meeting the performance of design. For reinforced concrete structures, the SL that the system must achieve is related to the performance level sought, which is presented in the performance standard [1].

Since ABNT NBR 15575 is not prescriptive, the performance requirements must be satisfied based on the design standards to which the structure is subjected. The standards adopted for reinforced concrete are ABNT NBR 6118 [3], ABNT NBR 6120 [4], ABNT NBR 8681 [5], ABNT NBR 6123 [6], and others. Except for ABNT NBR 6123 [6], the other standards prescribe requirements for a SL of 50 years [7]. To that end, foreign standards or technical studies with fundament must be consulted to reach intermediate and superior levels as they allow the adoption of consistent design criteria. Hence studies such as Bolina et al. [7] and Bolina and Tutikian $[8,9]$ serve as starting point for more sophisticated analyses that strive for $S L$ values above the minimum that have not been defined by Brazilian standards yet.

Concerning durability, the design parameters must contemplate external environmental agents. According to Tutikian and Helene [10], the durability of concrete structures depends on extrinsic factors such as the presence of salts, sea sprays, acid rain, and intrinsic factors, among which are the cement type, water-cement ratio, additions and admixtures. As presented by ABNT NBR 12655 [11] and, if the criteria set by ABNT NBR 6118 [3] have been met, the structures' durability depends directly on the characteristics of concrete and its surroundings. Due to correlations between the structure's characteristics and the concrete used, ABNT NBR 6118 [3] recommends the adoption of specific requirements to achieve the minimum durability prescribed. Bolina and Tutikian [8] assume that the recommendations of this standard regard a SL of 50 years. This assumption is based on ABNT NBR 8681 [5], which proposes increase factors for the combination of loads admitted for the period of 50 years. Thus, designs that seek to surpass the minimum performance level require an analysis of the design parameters of ABNT NBR 6118 [3].

Pertaining the loads admitted in the structural design, permanent loads do not change over time, so they do not change with respect to the SL sought [12]. On the other hand, accidental loads, or imposed loads, vary during service life and must be analyzed for performances levels that surpass the minimum. Because these loads vary over time, the Brazilian standard, ABNT NBR 8681 [5], suggests characteristic values that have from 25 to $35 \%$ of probability of occurring over a period of 50 years, disregarding any consideration for response times of 63 and 75 years to these actions [7].

As for wind action, ABNT NBR 6123 [6] states that it is necessary to use zones proposed when defining the wind speeds of each region. The values of the zones consider wind blasts of 3 seconds with $63 \%$ of probability of occurring once every 50 years. When a structure is designed to surpass the minimum performance levels, specific equations to determine the base wind speed must be used, as show in Attachment B of that standard.

It is then noted that the Brazilian system of standards applied to structural design still cannot deplete the requirements of ABNT NBR 15575 [1] for a SL of over 50 years. Regarding the costs, next to $40 \%$ of the total resources of the industry and $35 \%$ of construction works are directed towards repair of structures in an attempt to increase their SL $[13,14]$. However, the structural design does not hold information on the additional cost to reach performance levels above the minimum, that is, to increase SL. Therefore, this study

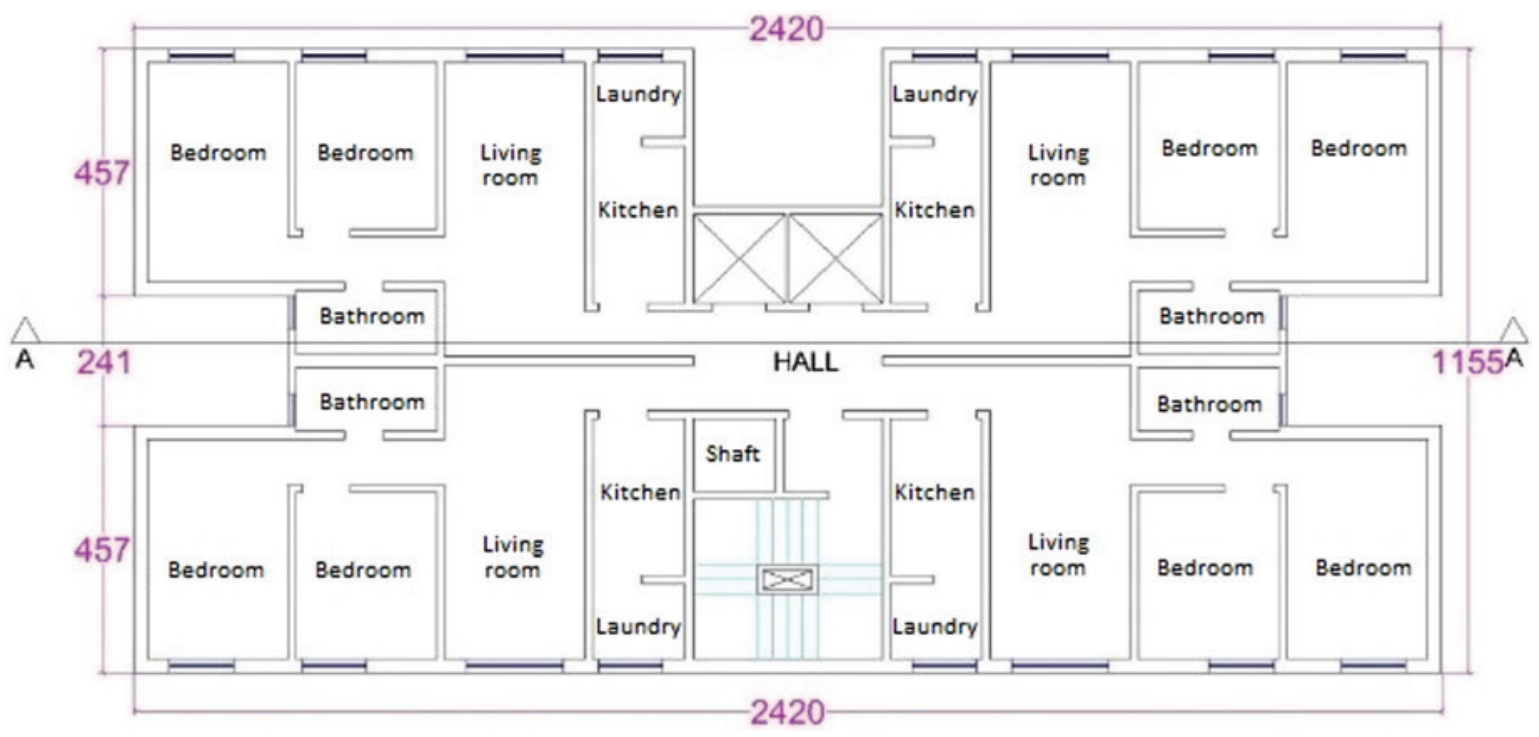

Figure 1

Plan view of the architectural design of the typical floor 


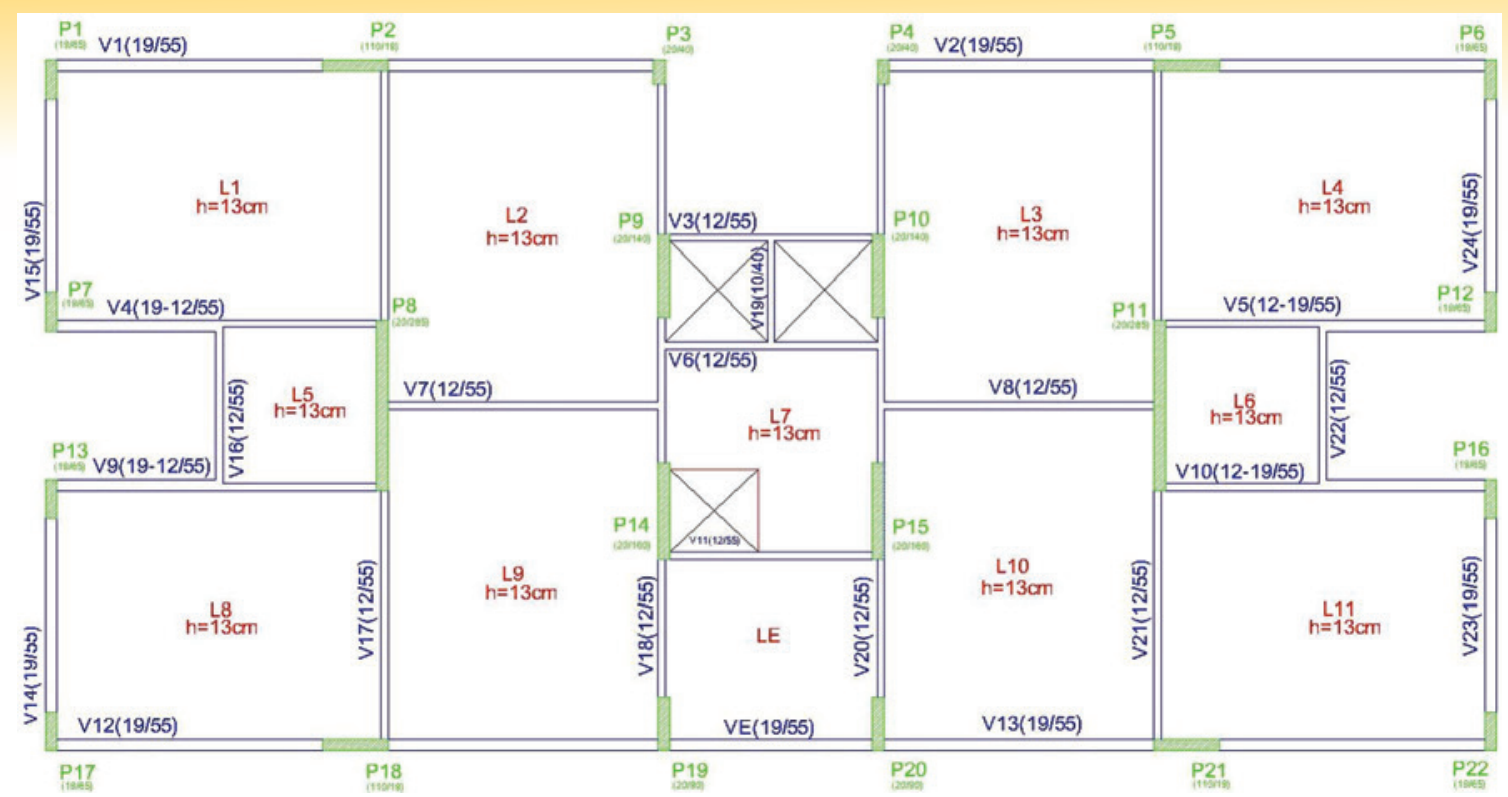

\section{Figure 2}

Plan view of the formwork of the typical floor

aims to dimension a single structure, namely a single hypothetical building, for the 3 performance levels prescribed in standard, using the 4 environmental exposure classes (EEC) of NBR 6118 [3], totalizing 12 designs, to assess the additional amount of materials incorporated to the system. The impact the performance level has on the amount materials of design of reinforced concrete structures was based on the concrete volume analysis and the total consumption of steel from reinforcements.

The variables considered for each project were: reinforcement cover thickness and compressive strength of concrete as durability parameters; and the magnitude of variable actions - including the wind - and their respective weighting coefficients as parameters of safety and structural dimensioning.

\section{Experimental procedures}

The criteria and parameters adopted for the 12 structural designs developed are presented as follows.

\subsection{Design}

The object of study is an architectural design of a residential building with nine floors. In total, 8 floors are leveled and one is the ground floor. Each leveled floor had area of $255.62 \mathrm{~m}^{2}$, with 4 apartments with two bedrooms, living room, kitchen, laundry and bathroom, depicted in Figure 1. On the ground floor stood the halls, corridors and commercial spaces, with the same area as the other floors.

The reinforced concrete structure is made of solid slabs, rectangular beams with spans of two to six meters, with ceiling height of $2.95 \mathrm{~m}$ between floors. The column placement was analyzed and determined as to contribute to the stiffness of the building. The beams bore loads from masonry walls, with sealing function and thickness of $12 \mathrm{~cm}$ and $14 \mathrm{~cm}$ for exterior and interior walls respectively. The structure was calculated with the computer-aided simulation software, Eberick $\circledast$ version 10, which informed the amount of materials of each project. During the dimensioning of structural elements, a degree of utilization next to $100 \%$ was sought. For the main reinforcements, type CA-50 steel was used, whereas the stirrups were made of type CA-60 steel. The 12 structural designs followed the same architectural design, keeping the placement of structural element and the preset areas of utilization, as per Figure 2. The simulation models remained unchanged.

\subsection{Procedure}

In order to reach the goal of this study, the baseline design was dimensioned for each one of 4 EECs defined by ABNT NBR 6118 [3]

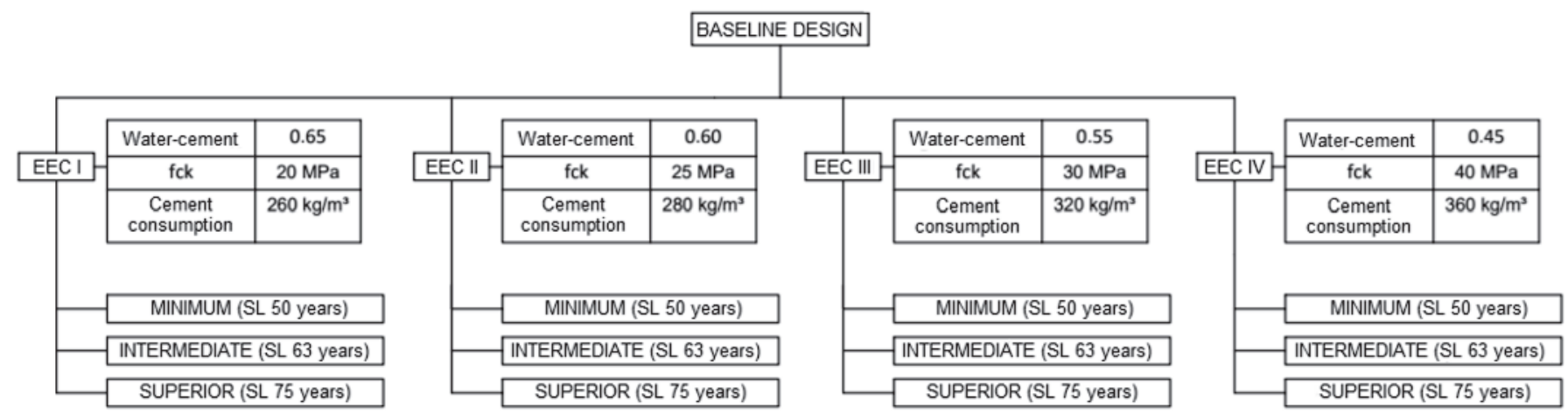

Figure 3

Project flow chart 
Table 1

Load values proposed for minimum, intermediate and superior performance of service life of durability for residential buildings

\begin{tabular}{|c|c|c|c|c|}
\hline \multirow{3}{*}{ Type } & \multirow{3}{*}{ Description } & \multicolumn{3}{|c|}{ Load $\left(\mathrm{kN} / \mathrm{m}^{2}\right)$} \\
\hline & & \multicolumn{3}{|c|}{ SL (years) } \\
\hline & & 50 & 63 & 75 \\
\hline \multirow{2}{*}{ Residential buildings } & Bedrooms, living room, pantry, kitchen e bathroom & 1.50 & 1.55 & 1.57 \\
\hline & Larder, service area and laundry & 2.00 & 2.05 & 2.09 \\
\hline \multirow{2}{*}{ Stairs } & With public access & 3.00 & 3.08 & 3.10 \\
\hline & No public access & 2.50 & 2.26 & 2.61 \\
\hline \multirow{3}{*}{ Balconies } & No public access & 2.00 & 2.06 & 2.09 \\
\hline & With public access & 3.00 & 3.08 & 3.13 \\
\hline & Inaccessible to people & 0.50 & 0.51 & 0.52 \\
\hline
\end{tabular}

and ABNT NBR 12655 [11]. The design variables were compressive strength, reinforcement cover and the magnitude of imposed loads and wind. Each EEC was subjected to dimensioning to the three performance levels of ABNT NBR 15575 [1], being them minimum, intermediate and superior. The flowchart of Figure 3 depicts the procedure undertaken.

\subsection{Loads considered}

Presuming that the building does not change, it was assumed that the weight of the structure itself does not change over time. The base for imposed loads was provided by Bolina and Tutikian [8], who had determined increase factors for accidental loads of a building when the intended service life is 63 and 75 years, that is, the intermediate and superior performance levels. Table 1 shows the values of variable actions for each SL mentioned in ABNT NBR 15575 [1]. The reference wind speed of design was defined in accordance with ABNT NBR 6123 [6]. For the topographic factor S1, a building on a flat terrain was considered, whose factor is equals 1 . For factor $\mathrm{S} 2$, which contemplates terrain roughness and building size, the structure was graded class $B$ as it presented the highest and lowest front dimension of wind action between $20 \mathrm{~m}$ and $50 \mathrm{~m}$, and category $\mathrm{V}$, which regards terrains covered by several big, tall obstacles with little space in-between, with factor equals 0.95 . Lastly, statistical factor $\mathrm{S} 3$, minding that the building has residential use, was assumed to be equals 1 . For periods that surpass 50 years, ABNT 6123 [6] presents in its Attachment $B$ a statistical method that corrects factor S3 with

\section{Table 2}

Reference wind speed for each SL

\begin{tabular}{cccc} 
& \multicolumn{3}{c}{ Base wind speed $\left(\mathrm{v}_{\mathbf{0}}\right)$} \\
\hline SL (years) & $\mathbf{5 0}$ & $\mathbf{6 3}$ & $\mathbf{7 5}$ \\
\hline $\mathrm{S} 1$ & 1.00 & 1.00 & 1.00 \\
$\mathrm{~S} 2$ & 0.95 & 0.95 & 0.95 \\
$\mathrm{~S} 3$ & 1.00 & 1.04 & 1.06 \\
$\mathrm{~V}_{0}(\mathrm{~m} / \mathrm{s})$ & 45.00 & 46.80 & 47.70 \\
\hline
\end{tabular}

respect to the 3-seconds return period of wind blasts, consequently changing the reference wind speed extracted from the zones, which is valid for a return period of 50 years. Applying the standard to SL of 63 and 73 years yielded S3 factors of 1.04 and 1.06 respectively. Therefore, considering the reference wind speed of $45 \mathrm{~m} / \mathrm{s}$ (Region $\mathrm{V}$ ) as the zones of the standard depict, Table 2 presents the design corrections proper to intermediate and superior performance levels.

\subsection{Durability parameters}

The durability parameters for ages higher than 50 years were defined after Bolina and Tutikian [8], who had used theoretical SL prediction models adjusted by the parameters of ABNT NBR 6118 [3], and foreign standards to extrapolate the service lives of 63 and 75 years, as per Table 3. It should be noted that, for the sake of the structural designs of this article, only reinforcement cover thickness and class of concrete strength were influential.

\section{Table 3}

Structural dimensioning parameters for durability for SL of 50, 63 and 75 years

\begin{tabular}{|c|c|c|c|c|c|c|c|c|c|c|c|c|c|}
\hline \multirow{2}{*}{$\begin{array}{c}\text { EEC } \\
\text { SL (years) }\end{array}$} & & \multicolumn{3}{|c|}{ I } & \multicolumn{3}{|c|}{ II } & \multicolumn{3}{|c|}{ III } & \multicolumn{3}{|c|}{ IV } \\
\hline & & 50 & 63 & 75 & 50 & 63 & 75 & 50 & 63 & 75 & 50 & 63 & 75 \\
\hline \multirow{4}{*}{ Slab } & C & 20 & 25 & 30 & 25 & 35 & 40 & 35 & 45 & 50 & 45 & 55 & 65 \\
\hline & CR & C20 & C25 & C30 & $\mathrm{C} 20$ & C35 & $\mathrm{C} 40$ & C30 & $\mathrm{C} 40$ & $\mathrm{C} 40$ & $\mathrm{C} 40$ & C50 & C50 \\
\hline & $A C$ & 0.65 & 0.60 & 0.60 & 0.60 & 0.50 & 0.50 & 0.55 & 0.45 & 0.40 & 0.45 & 0.40 & 0.40 \\
\hline & $\mathrm{CC}$ & 260 & 280 & 280 & 280 & 300 & 340 & 320 & 340 & 360 & 360 & 360 & 380 \\
\hline \multirow{4}{*}{ Beam/Column } & $\mathrm{C}$ & 25 & 30 & 35 & 30 & 40 & 45 & 40 & 50 & 55 & 50 & 60 & 70 \\
\hline & CS & $\mathrm{C} 20$ & $\mathrm{C} 25$ & $\mathrm{C} 30$ & $\mathrm{C} 25$ & C35 & $\mathrm{C} 40$ & C30 & $\mathrm{C} 40$ & $\mathrm{C} 40$ & C40 & C50 & C50 \\
\hline & WC & 0.65 & 0.60 & 0.60 & 0.60 & 0.50 & 0.5 & 0.55 & 0.45 & 0.40 & 0.45 & 0.40 & 0.35 \\
\hline & $\mathrm{CC}$ & 260 & 280 & 280 & 280 & 300 & 340 & 320 & 340 & 360 & 360 & 360 & 380 \\
\hline \multirow{4}{*}{$\begin{array}{l}\text { Elements in contact } \\
\text { with the ground }\end{array}$} & C & 30 & 30 & 40 & 30 & 40 & 45 & 40 & 50 & 55 & 50 & 60 & 70 \\
\hline & CS & C20 & $\mathrm{C} 25$ & C30 & $\mathrm{C} 25$ & C35 & $\mathrm{C} 40$ & C30 & $\mathrm{C} 40$ & C40 & C40 & C50 & C50 \\
\hline & WC & 0.65 & 0.60 & 0.60 & 0.60 & 0.50 & 0.45 & 0.55 & 0.45 & 0.40 & 0.45 & 0.35 & 0.35 \\
\hline & $\mathrm{CC}$ & 260 & 280 & 280 & 280 & 300 & 340 & 320 & 340 & 360 & 360 & 360 & 380 \\
\hline
\end{tabular}

$\mathrm{C}=$ cover $(\mathrm{mm}) ; \mathrm{CS}=$ class of concrete strength; $\mathrm{WC}=$ water-cement ratio; $\mathrm{CC}=$ cement consumption $\left(\mathrm{kg} / \mathrm{m}^{3}\right)$ 
Table 4

Comparison of material consumption for slabs

\begin{tabular}{|c|c|c|c|c|c|c|c|c|c|c|c|c|c|}
\hline \multicolumn{2}{|l|}{ EEC } & \multicolumn{3}{|c|}{$\mathbf{I}$} & \multicolumn{3}{|c|}{ II } & \multicolumn{3}{|c|}{ III } & \multicolumn{3}{|c|}{ IV } \\
\hline SL (years) & & 50 & 63 & 75 & 50 & 63 & 75 & 50 & 63 & 75 & 50 & 63 & 75 \\
\hline \multirow{3}{*}{$\begin{array}{l}\text { Steel consumption } \\
(\mathrm{kg})\end{array}$} & CA50 & 8570 & 8216 & 9950 & 8570 & 10196 & 11589 & 10259 & 11592 & 12660 & 11529 & 12259 & 14027 \\
\hline & CA60 & 817 & 1119 & 47 & 817 & 30 & 45 & 29 & 404 & 44 & 413 & 642 & 39 \\
\hline & Total & 9387 & 9335 & 9997 & 9387 & 10227 & 11633 & 10337 & 11996 & 12704 & 11942 & 12900 & 14066 \\
\hline \multicolumn{2}{|c|}{ Change in consumption (\%) } & 0 & -1 & 6.5 & 0 & 8.9 & 23.9 & 0 & 16.0 & 22.9 & 0 & 8.0 & 17.8 \\
\hline \multicolumn{2}{|c|}{ Class of concrete strength } & $\mathrm{C} 20$ & C25 & C30 & $\mathrm{C} 25$ & C35 & $\mathrm{C} 40$ & C35 & C40 & C40 & C40 & C50 & C50 \\
\hline \multicolumn{2}{|c|}{ Concrete volume $\left(\mathrm{m}^{3}\right)$} & 279 & 279.1 & 278.6 & 279 & 278.2 & 277.7 & 277 & 277.2 & 276.9 & 277.6 & 318.7 & 337.6 \\
\hline \multicolumn{2}{|c|}{ Change in consumption (\%) } & 0 & 0 & -0.2 & 0 & -0.3 & -0.5 & 0 & 0.1 & 0.0 & 0 & 14.8 & 21.6 \\
\hline \multicolumn{2}{|c|}{ Steel consumption $\left(\mathrm{kgf} / \mathrm{m}^{3}\right)$} & 33,6 & 33.4 & 35.9 & 33.6 & 36.8 & 41.9 & 37.1 & 43.3 & 45.9 & 43 & 40.5 & 41.7 \\
\hline
\end{tabular}

\section{Results and discussions}

\subsection{Slabs}

Table 4 presents, for the 4 EECs of ABNT NBR 6118 [3], a comparison of consumption of steel and concrete for slabs under different performance levels.

The increased reinforcement cover thickness, which is required to increase the performance level of the piece, did not provoke the remodeling of its geometry except for EEC IV. Since the areas of slabs were higher than those of beams and columns, these elements, when remodeling was needed, presented considerable increases of concrete consumption, reaching over $20 \%$ for the superior performance level of EEC IV.

When concrete consumption is stable, the loads generated by the increase of its own weight do not change and do not impact steel consumption. Therefore, the same initial thickness of the element $(13 \mathrm{~cm})$ was preserved. A slab with SL 75 years to EEC III loses about 15.8\% of its usable height when compared to the minimum performance, hence influencing the increase of area of steel required.

Slabs are subjected to bending moments and have longitudinal fibers in their rigid body that bear tensile and compressive stresses whose magnitudes vary according the circumstances of load and the element itself. Due to the low tensile strength of concrete, increasing compressive strength to comply with the durability parameter did not cause considerable effects to the stiffening of the piece on the stressed fibers.
Due to their slenderness and the type of stress borne, the slabs were sensitive to load changes. Hence, the increase of load related to SL, enhanced by the approximation of the reinforcement to the neutral axis in view of the increased cover thickness, causes the area of steel of the pieces to increase. For EEC III, increasing SL to 63 years changed steel consumption by $16.0 \%$. Comparing the least and most intense situations, EEC I and SL 50 years versus EEC IV and SL 75 years, steel consumption was $50 \%$ higher in the worse condition. The choice of performance level of reinforced concrete structures can then be decisive to the costs of the structure.

When EEC I is analyzed separately, though, it demonstrates that the increased steel consumption did not occur proportionately. Seeing that the load increased along with SL, no matter the EEC, and that cement consumption did not vary for EEC I, EEC II and EEC III, the disparity of the increased steel consumption took place from the usable height of the piece.

\subsection{Beams}

Table 5 compares the consumption of materials for beams among the multitude of performance levels and EEC.

Aiming to preserve the minimum bar spacing dictated by ABNT NBR 6118 [3], the elements had to be remodeled due to the variation of usable thicknesses. It is clear that, as SL and EEC increased, the requirements became stricter and pieces demanded an increase of material consumption. Comparing the most and least favorable conditions, namely EEC I and SL 50 years versus EEC IV and SL 75 years, the differences reached $33.0 \%$ for

Table 5

Comparison of material consumption for beams

\begin{tabular}{|c|c|c|c|c|c|c|c|c|c|c|c|c|c|}
\hline \multirow{2}{*}{$\begin{array}{c}\text { EEC } \\
\text { SL (years) }\end{array}$} & & \multicolumn{3}{|c|}{ 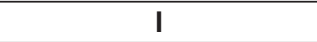 } & \multicolumn{3}{|c|}{ II } & \multicolumn{3}{|c|}{ III } & \multicolumn{3}{|c|}{ IV } \\
\hline & & 50 & 63 & 75 & 50 & 63 & 75 & 50 & 63 & 75 & 50 & 63 & 75 \\
\hline \multirow{3}{*}{$\begin{array}{l}\text { Steel consumption } \\
(\mathrm{kg})\end{array}$} & CA50 & 8217 & 8358 & 8368 & 8111 & 8001 & 8262 & 7878 & 8355 & 8522 & 8038 & 8738 & 9510 \\
\hline & CA60 & 1508 & 1503 & 1660 & 1505 & 1829 & 1878 & 1979 & 1863 & 1949 & 1841 & 2143 & 2389 \\
\hline & Total & 9725 & 9862 & 10028 & 9616 & 9830 & 10140 & 9857 & 10218 & 10471 & 9879 & 10881 & 11899 \\
\hline \multicolumn{2}{|c|}{ Change in consumption (\%) } & 0 & 1.4 & 3.1 & 0 & 2.2 & 5.4 & 0 & 3.7 & 6.2 & 0 & 10.1 & 20.4 \\
\hline \multicolumn{2}{|c|}{ Class of concrete strength } & $\mathrm{C} 20$ & $\mathrm{C} 25$ & C30 & $\mathrm{C} 25$ & $\mathrm{C} 40$ & C40 & C40 & $\mathrm{C} 40$ & C40 & $\mathrm{C} 40$ & C50 & C50 \\
\hline \multicolumn{2}{|c|}{ Concrete volume $\left(\mathrm{m}^{3}\right)$} & 148.1 & 148.1 & 154.9 & 148.1 & 157.9 & 164.8 & 159.7 & 168.3 & 174.6 & 165.5 & 179.5 & 197 \\
\hline \multicolumn{2}{|c|}{ Change in consumption (\%) } & 0 & 0 & 4.6 & 0 & 6.6 & 11.3 & 0 & 5.4 & 9.3 & 0 & 8.5 & 19.0 \\
\hline \multicolumn{2}{|c|}{ Steel consumption $\left(\mathrm{kgf} / \mathrm{m}^{3}\right)$} & 65.7 & 66.6 & 64.7 & 64.9 & 62.2 & 61.5 & 58.3 & 60.7 & 60 & 59.7 & 60.6 & 60.4 \\
\hline
\end{tabular}


Table 6

Comparativo de consumo de materiais nos pilares

\begin{tabular}{|c|c|c|c|c|c|c|c|c|c|c|c|c|c|}
\hline \multicolumn{2}{|l|}{ EEC } & \multicolumn{3}{|c|}{ I } & \multicolumn{3}{|c|}{ II } & \multicolumn{3}{|c|}{ III } & \multicolumn{3}{|c|}{ IV } \\
\hline SL (years) & & 50 & 63 & 75 & 50 & 63 & 75 & 50 & 63 & 75 & 50 & 63 & 75 \\
\hline \multirow{3}{*}{$\begin{array}{l}\text { Steel consumption } \\
(\mathrm{kg})\end{array}$} & CA50 & 6730 & 6934 & 6253 & 6595 & 6026 & 6016 & 6027 & 6023 & 6013 & 6023 & 5938 & 5930 \\
\hline & CA60 & 3402 & 3240 & 3220 & 3429 & 3067 & 3002 & 3061 & 2920 & 2854 & 2917 & 2773 & 2650 \\
\hline & Total & 10132 & 10174 & 9473 & 10024 & 9093 & 90 & 9137 & 8943 & 8867 & 8939 & 8712 & 8580 \\
\hline \multicolumn{2}{|c|}{ Change in consumption (\%) } & 0 & 0.4 & -6.5 & 0 & -9.3 & -10.0 & 0 & -2.1 & -3 & 0 & -2.5 & -4.0 \\
\hline \multicolumn{2}{|c|}{ Class of concrete strength } & $\mathrm{C} 20$ & $\mathrm{C} 25$ & C30 & $\mathrm{C} 25$ & $\mathrm{C} 40$ & $\mathrm{C} 2$ & C4 & C40 & $\mathrm{C}$ & C40 & C50 & C50 \\
\hline \multicolumn{2}{|c|}{ Concrete volume $\left(\mathrm{m}^{3}\right)$} & 138.2 & 138.2 & 138.2 & 138.2 & 138.2 & 138.2 & 138.2 & 138.2 & 138.2 & 138.2 & 138.2 & 141.0 \\
\hline \multicolumn{2}{|c|}{ Change in consumption (\%) } & 0 & 0 & 0 & 0 & 0 & 0 & 0 & 0 & 0 & 0 & 0 & 2.0 \\
\hline \multicolumn{2}{|c|}{ Steel consumption $\left(\mathrm{kgf} / \mathrm{m}^{3}\right)$} & 73.3 & 73.6 & 68.6 & 72.5 & 65.8 & 65.3 & 65.8 & 64.7 & 64.2 & 64.7 & 63.0 & 60.8 \\
\hline
\end{tabular}

concrete. The slabs turned out to be more sensitive than the beams under harsher conditions, even if both elements were subjected to tensile stresses.

The dimensions of the piece were increased on the base of their cross-section without changing their stiffness for tensile stresses, as in the increase of usable height. Still, considering the increased characteristic strength of concrete, the bigger dimension made the piece stiffer. In the end, the rate of steel per cubic meter was lower as the SL of EEC I and II increased, whereas the rate of reinforcements of EEC III and IV increased.

Nevertheless, the reduction at EEC I and II was a consequence of the increased concrete volume. When analyzed alone, steel consumption grew as the EEC and SL increased because the weight of slabs and beams and the imposed loads grew as well. Added to the reinforcement displacement and the reduction of usable height, steel consumption achieved an increase of up to $20.4 \%$ for EEC IV for SL 75 years.

\subsection{Columns}

Table 6 compares the consumption of materials for the columns with varying performance levels for the 4 EECs.
As the service life of columns increased, the reinforcement covers within a same EEC increased between $10 \%$ and $33 \%$. Concrete consumption did not vary, but the area of reinforcements did, suggesting that remodeling the section was not required, expect for EEC IV, as the section area of the column had to be increased by $2.0 \%$ due to the increased reinforcement cover that reached $50 \mathrm{~mm}$. The stabilization of concrete consumption was made possible by the increased compressive strength of concrete, attributable to the durability parameters. Whereas the minimum cover, another criterion, reduced the usable area of the piece, the increased moment capacity of the columns led to a reduction of the steel area needed, despite the increase of loads for a SL of 63 and 75 years, except for EEC II, whose durability parameters did not achieve the minimum level required for the increased concrete strength to be enough to resist the increased load. Figure 4 depicts the loss of usable area with respect to a total area equals $X$, along with the increased compressive strength, for a section of the regular design column with dimensions of $20 \times 90 \mathrm{~cm}$. As a result, for intermediate and superior performance, the minimum cover and strength parameters got equalized, stabilizing concrete consumption. However, the durability parameters led to higher cement consumption,

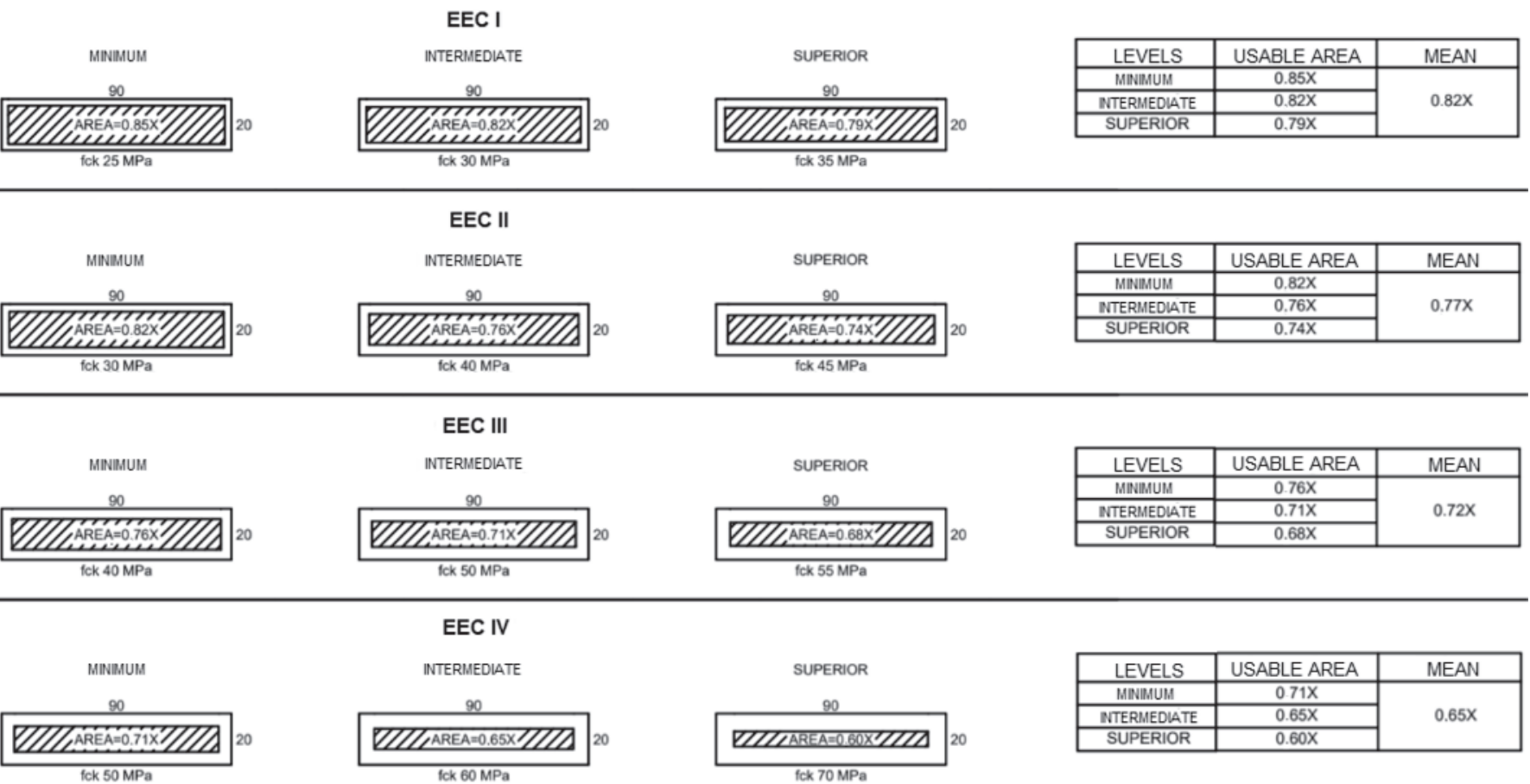

\section{Figure 4}

Comparison of the influence of durability parameters on usable area and strength of a column 
Table 7

Comparison of material consumption for the structure

\begin{tabular}{|c|c|c|c|c|c|c|c|c|c|c|c|c|}
\hline EEC & & $\mathbf{I}$ & & & II & & & III & & & IV & \\
\hline SL (years) & 50 & 63 & 75 & 50 & 63 & 75 & 50 & 63 & 75 & 50 & 63 & 75 \\
\hline Steel consumption $(\mathrm{kg})$ & 29244 & 29371 & 29498 & 29027 & 29149 & 30792 & 29382 & 31157 & 32043 & 30760 & 32492 & 34545 \\
\hline Change in consumption (\%) & 0 & 0.4 & 0.9 & 0 & 0.4 & 6.1 & 0 & 6.0 & 9.1 & 0 & 5.6 & 12.3 \\
\hline Concrete volume $\left(\mathrm{m}^{3}\right)$ & 565.4 & 565.4 & 571.7 & 565.4 & 574.3 & 580.6 & 574.9 & 583.7 & 589.7 & 581.3 & 631.4 & 675.6 \\
\hline Change in consumption (\%) & 0 & 0 & 1.1 & 0 & 1.6 & 2.7 & 0 & 1.5 & 2.6 & 0 & 8.6 & 16.2 \\
\hline
\end{tabular}

which causes more environmental impact. Still, the energy spent producing the steel and its environmental impact were lowered by the smaller consumption of the material.

Comparing the extreme cases, EEC I and SL 50 years versus EEC IV and SL 75 years, concrete consumption was $2.0 \%$ higher while steel consumption reduced $17.1 \%$. Such phenomenon demonstrates that the increase of concrete strength caused by the durability prescribed to reach service life ended up absorbing the increase of variable actions, resulting in the reduction of the necessary steel area.

\subsection{Structure}

Table 7 compares total material consumption for the structure among the multitude of performance levels and EEC.

The increased disparity of material consumption as EEC increases along performance levels. For EEC I, the increases of steel and concrete consumption necessary to reach the superior level were $0.9 \%$ and $1.1 \%$ respectively, whereas such increases were $16.2 \%$ and $12.3 \%$ for EEC IV. Thus, the higher the performance level sought, the higher the costs of implementation involved. The costbenefit of the structural system should still be analyzed, because SL can be increased by $50 \%$ keeping material consumption around $15 \%$ with the possibility of increasing system maintenance periods, reducing the utilization costs of the structure.

\section{Conclusions}

The main conclusions drawn from this study were:

- The Brazilian structural design standards are in need of compatibility regarding the new performance requirements of ABNT NBR 15575 [1], mainly the ones applied to SL for intermediate and superior performance levels;

- The increased structural performance level increased the dimensions of the pieces in some cases, considering the increased durability requirements, mainly with regards to reinforcement cover thickness;

- There were occasional reductions of the area of reinforcements used for dimensioning the sections. This comes from the fact that, although the acting loads grew along with the increases of the performance level sought due to the need to increase SL, the compressive strength of concrete was increased to meet the durability requirements;

- For SL higher than the minimum, an increase of up to $16 \%$ of concrete consumption was noted. Moreover, it was necessary to use with concretes of up to $50 \mathrm{MPa}$ of compressive strength, which increased overall costs;
- The higher the EEC applied to the design of the structure, the higher the impact of the performance level sought. For EEC I, changing from the minimum to the superior performance level increased steel consumption by $0.9 \%$ and the volume of concrete by $1.1 \%$. As for EEC IV, the respective increases were $12.3 \%$ and $16.2 \%$;

With the increase of performance level, the minimum dimensions recommended by ABNT NBR 6118 [3] could no longer be applied to the structural projects, in view of the increase of reinforcement cover thickness. For the study of structures with performance levels above the minimum, no significant increases to the dimensions of structural elements were observed.

- It should be verified that this paper did not take into account the fire safety requirements of reinforced concrete structures, as these are requirements that do not vary with the required Service Life, which could alter the results of the objectives established for this work. It is noteworthy that the analysis of concrete structures to fire is mandatory and must be done according to NBR 15200.

\section{References}

[1] ASSOCIAÇÃO BRASILEIRA DE NORMAS TÉCNICAS. Edifícios habitacionais - desempenho Parte 1: requisitos gerais - NBR 15575, Rio de Janeiro, 2013.

[2] LORENZI, L. S. Análise Crítica e Proposições de Avanço nas Metodologias de Ensaios Experimentais de Desempenho à Luz da ABNT NBR 15575 (2013) para Edificações Habitacionais de Interesse Social Térreas. 2013, Thesis (Doctorate) - Civil Engineering Graduate Program of Universidade Federal do Rio Grande do Sul, Porto Alegre, $222 \mathrm{p}$.

[3] ASSOCIAÇÃO BRASILEIRA DE NORMAS TÉCNICAS. Projeto de estruturas de concreto-Procedimento. - NBR 6118, Rio de Janeiro, 2014.

[4] ASSOCIAÇÃO BRASILEIRA DE NORMAS TÉCNICAS. Cargas para Cálculo de Estruturas de Edificações. - NBR 6120, Rio de Janeiro, 1980.

[5] ASSOCIAÇÃO BRASILEIRA DE NORMAS TÉCNICAS. Ações e segurança nas estruturas. - NBR 8681, Rio de Janeiro, 2003.

[6] ASSOCIAÇÃO BRASILEIRA DE NORMAS TÉCNICAS. Forças devidas ao vento em edificações. - NBR 6123, Rio de Janeiro, 1988.

[7] BOLINA, F.; PERRONE, v.; TUTIKIAN, B. Discussão sobre as ações variáveis de projeto segundo os requisitos mínimo, intermediário e superior de desempenho da ABNT NBR 15575. Revista concreto e construções, 2015, V.79, p.65-78.

[8] BOLINA, F.; TUTIKIAN, B. Especificação de parâmetros da 
estrutura de concreto armado segundo os preceitos de desempenho, durabilidade e segurança contra incêndio. Revista concreto e construções, 2015, V.79, p.24-38.

[9] BOLINA, F.; TUTIKIAN, B. Especificação frente à durabilidade para atender nível superior de desempenho em elementos estruturais enterrados. RIEM - Revista IBRACON de Estruturas e Materiais, 2016, V.9, n.2.

[10] TUTIKIAN, B. F.; HELENE, P. Dosagem dos concretos de cimento Portland. In: Ibracon. (Org.). Concreto: Ciência e Tecnologia - Ed. Geraldo Isaia. 1ed. São Paulo: Ibracon, 2011, v.1, p.415-452.

[11] ASSOCIAÇÃO BRASILEIRA DE NORMAS TÉCNICAS. Preparo, controle e recebimento - Procedimento. - NBR 12655, Rio de Janeiro, 2015.

[12] DIAS, A.; MALITE, M.; MUNAIR, J. Sistemas Estruturais. Elsevier Brasil, 2015, 2ed.

[13] GARCÍA-ALONSO, M. C.; ESCUDERO, M. L.; MIRANDA, J. M.; VEGA, M. I.; CAPILLA, F.; CORREIA, M. J.; SALTA, M.; BENNANI, A.; GONZÁLEZ, J.A. Corrosion behaviour of new stainless steels reinforcing bars embedded in concrete. Cement and Concrete Research, 37, p.1463-1471, 2007.

[14] MEHTA, P. K.; MONTEIRO, P.J.M. Concreto: microestrutura, propriedades e materiais. São Paulo: IBRACON, 2014. 